\title{
Immune responses in experimental allergic neuritis
}

\author{
R A C HUGHES, * M K A DLUBOWSKI, * I A GRAY, * A ND \\ S L E I B O W I T Z †
}

From the Deparment of Medicine* and the Department of Pathology, $\dagger$

Guy's Hospital Medical School, London

SUMMARY The antibody and cell mediated immune responses were investigated in inbred Lewis rats with experimental allergic neuritis (EAN) induced by either $P_{2}$, a protein purified from the bovine cauda equina nerve roots, or whole bovine nerve root myelin. In the $\mathrm{P}_{2}$ immunised animals both antibodies to $\mathrm{P}_{2}$ detected by radioimmunoassay and cell-mediated immunity to $\mathrm{P}_{2}$ assayed by skin testing appeared before the onset of EAN and persisted during and after the disease. In the myelin immunised animals the antibody titres were lower and somewhat delayed and the skin tests became negative at the height of the disease. Complement-fixing antibodies to galactocerebroside, which have been implicated in the production of demyelination under some circumstances, could not be detected in the serum after immunisation with either $\mathbf{P}_{2}$ or myelin. EAN was transferred passively with lymph node cells from rats immunised with either $\mathbf{P}_{2}$ or myelin although anti- $\mathrm{P}_{2}$ antibodies could not be detected in the serum of recipients with EAN. The results favour a cell-mediated immune response to $\mathrm{P}_{2}$ as the most important pathogenetic mechanism in EAN induced with whole myelin in the rat.

Experimental allergic neuritis (EAN) produced by immunisation with an emulsion of peripheral nerve and adjuvant is an important model of human acute inflammatory polyneuropathy (Guillain-Barré-Strohl syndrome) which it closely resembles histologically. Study of its immunological mechanisms was delayed because in most species the disease was contaminated by inflammation of the central nervous system, that is experimental allergic encephalomyelitis (EAE), and the identity of the neuritogenic antigen was not known. It has recently been shown that bovine peripheral nerve myelin injected into inbred Lewis rats produces pure EAN without EAE, ${ }^{123}$ and that $P_{2}$ basic protein purified from that myelin is responsible for the neuritogenic activity. ${ }^{145}$ This paper describes the humoral and cellular responses to $P_{2}$ during EAN and the passive transfer of the disease with lymph node cells.

\section{Methods}

Male inbred Lewis rats were injected as previously described $^{14}$ with $0.25 \mathrm{mg}$ bovine $P_{2}$ or $2.5 \mathrm{mg}$ bovine

Address for reprint request: Dr RAC Hughes, Department of Neurology, Guy's Hospital, London SE1 9RT, England.

Accepted 22 May 1981 peripheral nerve myelin, emulsified with adjuvant containing $0.5 \mathrm{mg}$ Mycobacterium tuberculosis, and killed after 7-42 days. The severity of neurological signs was graded $0=$ normal, $+=\operatorname{limp}$ tail, $++=$ paraparesis, $+++=$ paraplegia, tetraparesis or death. The mean scores in table 1 refer to the signs of 4-6 rats at the time of sacrifice when blood and lymph nodes were collected. The scores correspond closely to those obtained in previous experiments with 10 rats immunised with the same dose of $P_{2}$ and 10 with the same dose of myelin. Histological examination was

Table 1 Percentage ${ }^{125} I-P_{2}$ binding of sera from $P_{2}$ and myelin immunised rats in relation to neurological signs

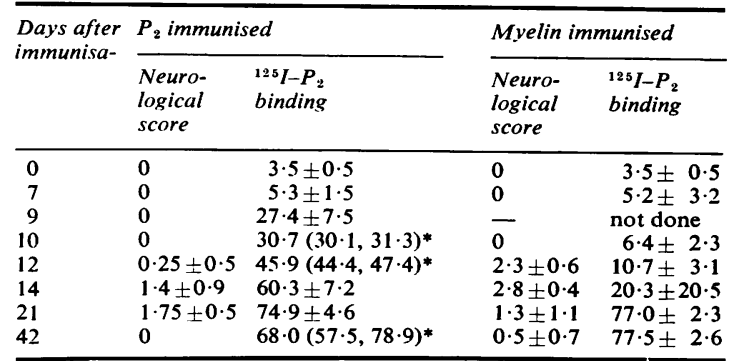

Mean \pm SD of 3-6 rats except for values marked * which are means of the two bracketed observations. 
performed on paraffin embedded sections of the sciatic nerves and cauda equina stained with haematoxylin and eosin or luxol fast blue. Antibodies to $P_{2}$ were detected by radioiodinating $P_{2}$ according to the method of Sarvas et al, ${ }^{6}$ incubating $2 \mathrm{ng}$ of this ${ }^{125} \mathrm{I}-\mathrm{P}_{2}$ with $50 \mu \mathrm{l}$ appropriately diluted test serum in a volume of $500 \mu \mathrm{l}$ overnight, and finally precipitating the bound $\mathrm{P}_{2}$ with $10 \%$ polyethylene glycol. The radioactivity of the precipitate was counted and expressed as a percentage of the total counts added. Skin tests were performed by injecting $50 \mu \mathrm{g} \mathrm{P}_{2}$ or purified protein derivative of tuberculin (PPD) in $0.1 \mathrm{ml}$ phosphate buffered saline intradermally into the flank of the rats under ether anaesthesia. The depth of induration was assessed 24 hours later by measuring the thickness of a fold of skin containing the skin test with calipers and subtracting the thickness of the skin fold on two sides.

Lymph node cell transformation was tested by a modification of our technique for human peripheral blood mononuclear cells. ${ }^{7}$ The rats were exsanguinated under ether anaesthesia and the draining axillary lymph nodes were dissected, teased in tissue culture medium, and sieved through a fine stainless steel mesh $(0.84 \mathrm{~mm})$. The lymph node cells were washed twice and cultured in the wells of a microtitre tray at 400,000 viable cells per well in Minimum Essential Medium modified with Earle's Salts (Flow Lab 12-10249) containing hepes $20 \mathrm{mM}, 10 \%$ human AB serum, glutamine $200 \mathrm{mM}$, penicillin and streptomycin. The required amounts of antigen were added and the cultures were incubated in a humidified $5 \% \mathrm{CO}_{2}$ atmosphere at $37^{\circ} \mathrm{C}$. The cells were harvested after 72 hours, 20 hours after the addition of $0.8 \mu \mathrm{Ci}{ }^{3} \mathrm{H}$ thymidine.

In the lymph node cell transfer experiments the antigen emulsion for the donors was usually distributed between all four feet. All the lymph nodes were harvested after 9 or 21 days and then teased and sieved to prepare a single cell suspension. The cells were washed twice and then injected into the dorsal penile vein in a volume of $1-2 \mathrm{ml}$. The recipients were observed daily and killed after 14 days. Antibodies to galactocerebroside were sought with a micro-complement fixation test with $5 \mu \mathrm{g}$ galactocerebroside, and cholesterol and lecithin as auxiliary lipids.

\section{Results}

The neurological signs produced by whole peripheral nerve myelin were similar but more severe than those produced by $P_{2}$ (table 1 ). After 11-12 days the rats developed limp tails, then hind limb paresis and sometimes paraplegia, tetraparesis or death. With the doses used all the rats became affected after 14 days. The histological appearances of cellular infiltration and demyelination, assessed on paraffin fixed material stained with haematoxylin and eosin or luxol fast blue, were similar in rats immunised with either purified $P_{2}$. protein or whole myelin.

After immunisation with $\mathrm{P}_{2}$ increased ${ }^{125} \mathrm{I}-\mathrm{P}_{2}$ binding was detected in the serum at nine days, rose until 21 days and remained high at 42 days (table 1). After immunisation with whole myelin the ${ }^{125} \mathrm{I}-\mathrm{P}_{2}$ binding rose more slowly, but by 21 days achieved a level similar to that after $P_{2}$ immunisation. Rats immunised with adjuvant alone did not produce significant ${ }^{125} \mathrm{I}-\mathrm{P}_{2}$ binding (the mean percentage binding of 11 samples was $3 \cdot 8 \pm 0 \cdot 7)$. Complement fixing antibodies to galactocerebroside were not detected in any of the sera although rabbit antigalactocerebroside antiserum reacted strongly in the same test.

In 21 complete adjuvant immunised control rats injection of $\mathbf{P}_{2}$ produced no erythema or induration (mean depth of induration $\pm S D=0.00 \pm 0.04$ $\mathrm{mm})$. In the $P_{2}$ and myelin immunised animals $P_{2}$ produced positive skin tests 7-10 days after immunisation (table 2). The induration was less than with similar tests with PPD (table 3) and erythema, although present, was difficult to measure accurately. In the $P_{2}$ immunised rats the positive skin tests persisted during the disease whereas in the myelin immunised rats the skin reaction to $P_{2}$ and PPD diminished (tables 2 and 3 ).

In the lymph node cell transformation tests, addition of $P_{2} 100 \mu \mathrm{g} / \mu \mathrm{l}$ produced an increment in ${ }^{3} \mathrm{H}$-thymidine incorporation of lymph node cells from all the groups of rats. Only the cells from the rats immunised with pure $P_{2}$ had a significantly

Table 2 Skin tests with $50 \mu g P_{2}$ in $P_{2}$ and myelin immunised rats

\begin{tabular}{llc}
\hline Days after immunisation & $P_{2}$ immunised rats & Myelin immunised rats \\
\hline 7 & $0 \cdot 13 \pm 0 \cdot 1$ & $0.22 \pm 0.08$ \\
10 & $0.47 \pm 0.28$ & $0.27 \pm 0.16$ \\
12 & $0.43 \pm 0.06$ & $0.37 \pm 0.16$ \\
14 & $0.43 \pm 0 \cdot 15$ & $-0.125 \pm 0.12$ \\
21 & $0.30 \pm 0.10$ & $0.02 \pm 0.03$ \\
42 & $0.40 \pm 0.11$ & $0.02 \pm 0.14$ \\
\hline
\end{tabular}

Mean induration $(\mathrm{mm}) \pm \mathrm{SD}$ for 4 rats.

Table 3 Skin tests with $50 \mu g$ PPD in adjuvant, $P_{2}$ and myelin immunised rats

\begin{tabular}{lccc}
\hline $\begin{array}{l}\text { Days after } \\
\text { immunisation }\end{array}$ & $\begin{array}{l}\text { Adjuvant } \\
\text { immunised rats }\end{array}$ & $\begin{array}{l}P_{2} \text { immunised } \\
\text { rats }\end{array}$ & $\begin{array}{l}\text { Myelin } \\
\text { immunised rats }\end{array}$ \\
\hline 0 & $-0.05^{*}$ & $-0.05^{*}$ & $-0.05^{*}$ \\
7 & $0.61 \pm 0.15$ & $0.31 \pm 0.14$ & $0.23 \pm 0.19$ \\
10 & $1.08 \pm 0.09$ & $1.02 \pm 0.21$ & $0.68 \pm 0.40$ \\
12 & $1.04 \pm 0.21$ & $1.00 \pm 0.44$ & $1.30 \pm 0 \cdot 36$ \\
14 & $1.76 \pm 0.67$ & $1.56 \pm 0.55$ & $0.18 \pm 0 \cdot 10$ \\
21 & $0.93 \pm 0.11$ & $0.38 \pm 0.18$ & Not done \\
42 & $0.50 \pm 0.10$ & $0.49 \pm 0.23$ & $0.20^{*}$ \\
\hline
\end{tabular}

Mean induration $(\mathrm{mm}) \pm \mathrm{SD}$ for 4 rats.

*One observation. 
larger increment than those from normal rats (table 4). $P_{2} 20 \mu \mathrm{g} / \mathrm{ml}$ caused increased transformation only of the cells from rats immunised with $P_{2}$.

Six animals received a single intraperitoneal injection of 9-12 $\mathrm{ml}$ of pooled antimyelin serum. Four of these were given serum from rats immunised 21 days earlier with $2.5 \mathrm{mg}$ bovine myelin; one received 14 day and another 9 day serum. No neurological signs were observed during the next two weeks and no histological evidence of demyelination or inflammation was found in the sciatic nerves or cauda equina. By contrast mild neurological signs and mild or moderate cellular infiltration of the sciatic nerves and cauda equina were consistently observed following transfer of $2.0 \times 10^{8}$ or more lymph note cells from donors sensitised nine days earlier with $\mathrm{P}_{2}$ or myelin (table 5). Thymocytes and splecn cells from the same donors were ineffective. The effect was lost if the cells were killed by heating to $56^{\circ}$ for 30 minutes. Lymph node cells from donors sensitised 21 days earlier did not transfer the disease nor did lymph node cells from donors immunised with adjuvant alone. The ${ }^{125} \mathrm{I}-\mathrm{P}_{2}$ binding of the sera of the two rats with passively transferred

Table 4 Lymph node cell transformation in the presence of $P_{2} 14$ days after immunisation

\begin{tabular}{lclcc}
\hline Immunisation & $\begin{array}{l}\text { Noof } \\
\text { rats }\end{array}$ & $\begin{array}{l}\text { Background } \\
\text { incorporation } \\
\text { without } \\
\text { antigen }\end{array}$ & $\begin{array}{l}\text { Increment } \\
\text { with } P_{2} \\
\text { I00 } \mu / m l\end{array}$ & $\begin{array}{l}\text { Increment } \\
\text { with } P_{2} \\
20 \mu \mathrm{g} / \mathrm{ml} l\end{array}$ \\
\hline None & 10 & $280 \pm 310$ & $530 \pm 670$ & $90 \pm 140$ \\
Adjuvant alone & 9 & $300 \pm 330$ & $810 \pm 1000$ & $88 \pm 100$ \\
$P_{2}$ & 8 & $270 \pm 150$ & $2790 \pm 1250^{*}$ & $450 \pm 210^{*}$ \\
Myelin & 3 & $470 \pm 190$ & $850 \pm 370$ & $40 \pm 190$ \\
\hline
\end{tabular}

${ }^{3} \mathrm{H}$-thymidine incorporation per $\mathbf{4 0 0 , 0 0 0}$ cells. Mean $\pm S D$, DPM. *The increment with $P_{2}$ of the cells from $P_{2}$ immunised rats is greater than that of cells from the normal rats $(p<0.01$, two-tailed Wilcoxon rank sum test) or of the cells from the adjuvant immunised rats $(\mathrm{p}<0.01)$.
EAN in experiment 6 was $2 \cdot 7 \%$ and $4 \cdot 1 \%$, not significantly different from that of normal rats (table 1). On the other hand the serum of the recipient of 21 day cells in experiment 9 bound $8.9 \%$ indicating the presence of circulating antibody although no neurological signs or histological lesions of EAN were detected.

\section{Discussion}

Immunisation of Lewis rats with either whole bovine intradural root myelin or purified $P_{2}$ stimulates production of antibodies to $P_{2}$ which are readily detected by our ${ }^{12 .} \mathrm{I}-\mathrm{P}_{2}$ binding assay. The antibody level does not correspond closely to the course of the neurological signs of EAN (table 1). For instance in the $\mathbf{P}_{2}$ immunised animals although circulating antibody was clearly present on day nine, one or two days before the onset of neurological signs, peak levels were not achieved until after 21 days by which time surviving animals had either recovered or were improving. The antibodies remained at a high level at 42 days when all the rats had recovered. In the myelin immunised animals the discrepancy between antibody levels and appearance of neurological signs was even more obvious since the antibody levels remained relatively low at 12 and 14 days, although these rats were more severely affected than those immunised with $P_{2}$. The method used investigated $\mathrm{P}_{2}$ bound by all classes of antibody so that the present experiments do not eliminate the possibility that minor subclasses of immunoglobulin or tissue bound antibody play a part.

The absence of complement-fixing antibodies to galactocerebroside from the serum of rats with EAN makes it unlikely that these play a part in the pathogenesis of EAN under the conditions of these experiments. Under other circumstances antibodies to galactocerebroside are important in

Table 5 Induction of EAN by passive transfer of cells

\begin{tabular}{|c|c|c|c|c|c|c|c|c|}
\hline \multirow[t]{2}{*}{ Experiment } & \multirow{2}{*}{$\begin{array}{l}\text { Cell } \\
\text { type }\end{array}$} & \multirow[t]{2}{*}{ Immunogen } & \multirow{2}{*}{$\begin{array}{l}\text { Day of } \\
\text { transfer }\end{array}$} & \multirow{2}{*}{$\begin{array}{l}\text { No of cells } \\
\text { transferred } \times 10_{8}\end{array}$} & \multicolumn{2}{|c|}{ Neurological signs } & \multicolumn{2}{|c|}{ Histological disease } \\
\hline & & & & & Incidence & Score & Incidence & Score \\
\hline 1 & LNC* & myelin & 9 & $2 \cdot 8$ & $3 / 4$ & 0.75 & $4 / 4$ & $2 \cdot 0$ \\
\hline 2 & LNC & myelin & 9 & $2 \cdot 0$ & $0 / 3$ & 0 & $2 / 3$ & 0.75 \\
\hline \multirow[t]{3}{*}{3} & LNC & & & & $2 / 2$ & $1 \cdot 0$ & $2 / 2$ & $2 \cdot 5$ \\
\hline & thymus & $P_{2}$ & 9 & $2 \cdot 0$ & $0 / 2$ & 0 & $0 / 2$ & 0 \\
\hline & spleen & & & & $0 / 2$ & 0 & $0 / 2$ & 0 \\
\hline 4 & LNC & myelin & 9 & $2 \cdot 0$ & $2 / 3$ & 0.67 & $3 / 3$ & $1 \cdot 67$ \\
\hline \multirow[t]{2}{*}{5} & LNC & $\mathrm{P}_{2}$ & 9 & $4 \cdot 0$ & $2 / 2$ & $2 \cdot 0$ & $2 / 2$ & $2 \cdot 0$ \\
\hline & LNC & & & $4 \cdot 0 \dagger$ & $0 / 2$ & 0 & $0 / 2$ & 0 \\
\hline 6 & LNC & $P_{2}$ & 9 & $2 \cdot 5$ & $2 / 2$ & $1 \cdot 5$ & $2 / 2$ & $2 \cdot 0$ \\
\hline 7 & LNC & myelin & 21 & $2 \cdot 0$ & $0 / 2$ & 0 & $0 / 2$ & 0 \\
\hline 8 & LNC & $P_{2}$ & 21 & $2 \cdot 5$ & $0 / 1$ & 0 & $0 / 1$ & 0 \\
\hline 9 & LNC & myelin & 21 & $2 \cdot 0$ & $0 / 1$ & 0 & $0 / 1$ & 0 \\
\hline
\end{tabular}

LNC $=$ lymph node cells.

$\dagger=$ cells killed by heating at -56 for 30 minutes before injection. 
immune mediated demyelination since rabbits repeatedly immunised with galactocerebroside develop demyelination and macrophage infiltration, ${ }^{9}$ which can be reproduced by intraneural injections of antigalactocerebroside serum. ${ }^{10}$ The myelin splitting preceding cellular infiltration and prominent Schwann cell death in the galactocerebroside induced lesion are not described in EAN induced by whole nerve or myelin ${ }^{11}$ nor have we noted them in our own material. Hoffman et $a l^{3}$ were unable to produce disease in rats with galactocerebroside so that species differences are probably important.

The time course of skin test responses to $\mathrm{P}_{2}$ did not correspond to the development and disappearance of neurological signs any more closely than the antibody levels (table 2). In the $P_{2}$ immunised rats the skin test became positive after 10 days just before the onset of neurological signs and remained positive for the next three weeks. In the myelin immunised rats a positive skin test reaction with $P_{2}$ appeared at 7-12 days but then disappeared despite the fact that these animals had disease which was at least as severe as those immunised with $P_{2}$. The skin test reaction with PPD was depressed in the $P_{2}$ immunised rats after 21 days and the myelin immunised rats after 14 days compared with the adjuvant immunised controls. It is possible that the disappearance of the positive skin test to $P_{2}$ in the myelin immunised animals and depression of PPD response in both groups represents a non-specific response to stress. Another possible mechanism would be that the available sensitised cells have left the circulation having been attracted by the target antigen in the peripheral nerve or adjuvant depots. An analogous phenomenon was described in EAE in which the skin test to myelin basic protein decreased at the height of the disease. ${ }^{12}$

A positive test of specific transformation in the presence of $P_{2}$ was clearly demonstrated only with lymph node cells from the $P_{2}$ and not the myelin immunised rats. Since the myelin immunised rats had more severe EAN than those immunised with $P_{2}$ it is evident that whatever immunological reaction is responsible for the disease may occur in the absence of a positive result with this sensitive in vitro test of cellmediated immunity. This observation is very relevant to the search for evidence of cell-mediated immunity in human acute inflammatory polyneuropathy. It was interesting that $P_{2}$ caused some transformation of lymph node cells from adjuvant immunised or normal rats: this might be a non-specific biochemical or mitogenic effect but might also indicate a universal weak immunological response to a species-specific component or even the autoantigen itself. It would be interesting to discover whether $P_{2}$ has a similar effect on other cells, particularly Schwann cells, which proliferate following myelin breakdown with associated release of $\mathbf{P}_{2}$.

The failure to transfer disease with acute or convalescent serum by intravenous injection and the successful transfer with lymph node cells favour a cell-mediated immune mechanism. Successful passive transfers of EAN with lymph node cells have previously been performed with three rabbits following irradiation of the recipients. ${ }^{13}$ Mild histological lesions of EAN were also reported in guinea-pigs to which had been transferred cells from guinea-pigs immunised with a basic protein derived from human sciatic nerve myelin, ${ }^{14}$ an observation which we find difficult to equate with our own demonstration that in the guinea-pig human $\mathrm{P}_{2}$ basic protein produces predominantly EAE rather than EAN. ${ }^{15}$ Injection of cells from rats with EAN directly into the sciatic nerves of rats produced rather more inflammation and demyelination than injection of control cells. ${ }^{16}$ EAN serum directly injected into rat sciatic nerve also causes extensive demyelination preceded by Schwann cell damage and accompanied by vesicle formation of the inner myelin lamellae. ${ }^{917}$ These direct injections bypass the blood-nerve barrier and the pathological changes may not represent what occurs in EAN actively induced by the usual emulsion of nerve and adjuvant. In the present experiments EAN was passively transferred with intravenous injections and the absence of antibody to $P_{2}$ from the serum of recipients which developed EAN makes it unlikely that our passively transferred disease is caused by circulating antibody. The possibility that B cells and locally produced antibody play a role as well as $T$ cells cannot be excluded without dissection of the cellular mechanisms with $\mathbf{B}$ and $\mathrm{T}$ cell depleted rats. In EAE similar experiments favour a $T$ cell-mediated mechanism. ${ }^{18}$ The failure of 21 day cells to produce transfer could be due to disappearance of "neuritogenic" cells from the lymph nodes: preliminary experiments mixing 9 and 21 day cells have provided no evidence of suppression.

There are reports of antibody to crude nerve extracts $^{19}$ and positive in vitro tests of cellmediated immunity to more or less purified nerve extracts in human acute inflammatory polyneuropathy. ${ }^{20}$ If this human disease is as closely related to EAN as the histological similarity sug- 
gests, it will be important to confirm whether cell-mediated immunity to $P_{2}$ is present. ${ }^{21}$ Despite the arguments which have been advanced against an important pathogenetic role for antibodies to $\mathrm{P}_{2}$ in EAN, their presence does provide a readily detected and persistent marker of the autoimmune reaction. If EAN is a relevant model for human inflammatory polyneuropathy it would be expected that antibodies to $P_{2}$ would be demonstrable in the serum.

This work was supported by the Medical Research Council.

\section{References}

1 Kadlubowski $\mathbf{M}$, Hughes RAC. Identification of the neuritogen responsible for EAN. Nature 1979; 277:140-1.

2 Smith ME, Forno LS, Hofmann WW. Experimental allergic neuritis in the Lewis rat. $J$ Neuropathol Exp Neurol 1979; 38:377-91.

3 Hoffman PM, Powers JM, Weise MJ, Brostoff SW. EAN I. Rat strain differences in the response to bovine myelin antigens. Brain Res 1980; 195: 355-62.

4 Kadlubowski M, Hughes RAC, Gregson NA. Experimental allergic neuritis in the Lewis rat: characterisation of the activity of peripheral myelin and its major basic protein, $\mathrm{P}_{2}$. Brain Res 1980; 184:439-54.

5 Suzuki M, Kitamura K, Uyemura K, Ogawa Y, Ishihara $Y$, Matsuyama $H$. Neuritogenic activity of peripheral nerve myelin proteins in Lewis rats. Neuroscience Letters 1980; 19:353-8.

6 Sarvas HO, Milek DJ, Weise MJ, Carnow TB, Fudenberg $\mathrm{HH}$, Brostoff SW. RIA for the $\mathbf{P}_{2}$ protein of bovine peripheral nerve myelin. $J$ Immunol 1980; 124:557-64.

7 Hughes RAC, Gray IA, Clifford-Jones R, Stern MA. Lymphocyte transformation in the presence of myelin basic protein in multiple sclerosis and control subjects. Acta Neurol Scandinav 1979; 60:65-76.

8 Hughes RAC, Stedronska J. The susceptibility of rat strains to experimental allergic encephalomyelitis. Immunology 1973; 24:879-84.

9 Saida T, Saida K, Dorfman SH, Silberberg DH, Sumner AJ, Manning MC, Lisak RP, Brown MJ. EAN induced by sensitisation with galactocerebroside. Science 1979; 204:1103-6.

10 Saida T, Saida K, Silberberg DH, Brown MJ. Transfer of demyelination by intraneural injection of EAN serum. Nature 1978; 272:649-1.

11 Lampert PW. Mechanism of demyelination in EAN. EM studies. Lab Invest 1969; 20:127-38.

12 Shaw MC, Alvord EC, Kaku J, Kies MW. Correlation of EAE with delayed-type skin hypersensitivity to specific homologous encephalitogen. Ann NY Acad Sci 1965; 122:318-31.

13 Aström KE, Waksman BH. The passive transfer of experimental allergic encephalomyelitis and neuritis with living lymphoid cells. J Path Bact 1962; 83:89-102.

14 Abramsky O, Teitelbaum D, Arnon R. Experimental allergic neuritis induced by a basic neuritogenic protein $\left(\mathrm{P}_{1} \mathrm{~L}\right)$ of human peripheral nerve origin. Eur J Immunol 1977; 7:213-7.

15 Kadlubowski M, Hughes RAC. The neuritogenicity and encephalitogenicity of $P_{2}$ in the rat, guinea-pig and rabbit. $J$ Neurol $S c i$ 1980; 48: 171-8.

16 Arnason BGW, Chelmicka-Szorc E. Passive transfer of EAN in Lewis rats by direct injection of sensitised lymphocytes into the sciatic nerve. Acta Neuropathol (Berl) 1972; 22:1-6.

17 Hahn AF, Gilbert JJ, Feasby TE. Passive transfer of demyelination by EAN serum. Acta Neuropathol (Berl) 1980; 49:169-76.

18 Ortiz-Ortiz L, Weigle WO. Cellular events in the induction of EAE in rats. J Exp Med 1976; 144: 604-16.

19 Nyland H, Aarli JA. Guillain-Barré syndrome: demonstration of antibodies to peripheral nerve tissue. Acta Neurol Scandinav 1978; 58:35-43.

20 Hughes RAC. Acute inflammatory polyneuropathy. In: Rose FC, ed. Clinical Neuroimmunology. Oxford: Blackwell, 1979; 170-84.

21 Sheremata WA, Colby S, Karkhanis Y, Eylar E. Cellular hypersensitivity to basic myelin $\left(\mathrm{P}_{2}\right)$ protein in the Guillain-Barré syndrome. Can $J$ Neurol Sci 1975; 2:87-90. 